\title{
Litigation Ethics: A Niebuhrian View of the Adversarial Legal System
}

\author{
Eric E. Jorstad
}

Law is the juncture of power and justice in American society. The practicing litigator wants to use the law as a tool of power for his client-he wants to win the case or a favorable settlement. For the litigator, legal procedures and substantive law are tools in the exercise of power. Of course, the opposing party's litigator has access to the same tools and seeks precisely the same power in the law. This creates the great drama (or sport) of the adversarial system.

From a different perspective, judges, juries, the public, and philosophers generally look to the law for justice. Legal procedures are, in this view, tools for discovering the truth; once the truth is known substantive laws can be applied to make the situation right. Litigators, therefore, should be limited in their advocacy by the law's higher commitment to truth-seeking and justice. Litigation is less a combat drama than it is a public moral debate over which side deserves to win.

How can a litigator pursue both power and justice? Is a litigator a tool of power or an agent of justice? What is a litigator who takes ethics seriously to do?

This Note will consider this dilemma by using Reinhold Niebuhr's moral realism as a basis to criticize and reconstruct the conventional approaches to litigation ethics. ${ }^{1}$ The Note will argue that litigation ethics cannot be fully understood except in the broader context of political philosophy and that Niebuhr's political philosophy can illuminate the ethical dilemmas of litigation. Conventional legal ethicists have failed to see that political philosophy is an essential framework in which to understand the study of legal ethics.

Niebuhr himself rarely applied the insights from his philosophy to the field of law. ${ }^{2}$ It is but a small step, however, to cross from political theory

1. There is no standard field of study called "litigation ethics." There is regular study of legal ethics, civil procedure, the philosophy of law, and the legal profession-this Note could come under any of these rubrics-but since the focus of this Note is specifically on the foundations for reflecting on ethics in litigation, the new term "litigation ethics" has been coined. As will become clear, litigation is the part of legal ethics to which Niebuhr's insights can most logically be applied.

2. Niebuhr wrote extensively about law in the biblical, theological sense-the law of God revealed by Scripture and reason-but he rarely applied his concepts to positive law or to legal practice, see infra notes 23 and 73 and accompanying text (examples of Niebuhr on civil law). For a discussion of Niebuhr's view of law in the theological sense, see Ramsey, Love and Law, in REINHOLd NIEBUhr: 
to legal ethics; law is the procedural face of governance. ${ }^{3}$ For example, read "law" for Niebuhr's "politics" in the following theme statement of his political philosophy: "Politics will, to the end of history, be an area where conscience and power meet, where the ethical and coercive factors of human life will interpenetrate and work out their tentative and uneasy compromises." Niebuhr's political philosophy is built on a fundamental tension between power and justice. This tension is unresolvable, yet we constantly fall prey to the illusion that one side or the other can be ignored or eliminated. Very few public actions can fulfill the demands both of power and of justice; virtually every public action is to a certain extent misguided and incomplete, an exercise of power that falls short of justice or a seeking after justice which misconstrues the realities of power. Public actions, therefore, are always provisional and must be subject to careful scrutiny and open to constant revision. This Note will adopt as its method what Niebuhr called the search for "proximate solutions for insoluble problems."'s

This Note will delineate this tension in litigation, with an eye both to practicing litigators and to those who oversee litigation-judges, ruledrafters, ethicists, and ultimately the public. Litigators can find insight into a foundational philosophy in Niebuhr's moral realism. Niebuhr's perceptions about human nature and society can help one both plan power strategies and wrestle with the quest for justice in imperfect institutions. The ethical litigator must grapple with a fundamental question: How does a litigator mediate between the state's interest in the litigation and the private parties' struggle for power through the law? This Note will use Niebuhr's concepts to show that litigators are mediators between the state and private actors; litigators' decisions affect the way private conflicts over power are pursued and they affect the norms of the law itself. Litigators change both their clients and the law. Whether these powers of litigators actually assist or hinder the quest for justice is a question litigators-and the legal profession-should constantly ask of themselves.

Those who oversee litigation can learn from Niebuhr that because the tension between power and justice is unresolvable, the best they can achieve are provisional standards subject to rigorous and ongoing public scrutiny. Overseers should not be satisfied with the standards of the moment, and they should be aware that the interests of litigators who recom-

His Religrous, Social, and Political Thought 144 (C. Kegley rev. ed. 1984); Rice, The Spirit of the Law in the Thought of Reinhold Niebuhr, 4 J.L. \& ReLigron 253 (1986).

3. All lawyers participate in governance in two important respects. First, the lawyer is an "officer of the legal system," Model Rules of Professional. Conduct Preamble (1983), although this phrase makes the lawyer's role too much like that of a state-functionary. Second, lawyers are able to invoke the power of the state on behalf of their clients.

4. R. Niebuhr, Moral. Man and Immoral Society 4 (1932).

5. R. Niebuhr, The Children of Light and the Children of Darkness 118 (2d ed. 1972). 
mend standards may not be identical to the public interest. This Note will argue that public scrutiny of litigation is best undertaken by focusing on the nature of the state's interest in the litigation and on what the state should expect of the litigator who must mediate the state's interest with that of the client, especially given the litigator's power to effect changes in the law. This focus connects litigation ethics to political theory.

This Note is divided into three parts. Section I introduces Reinhold Niebuhr's political philosophy of moral realism. Section II turns to the work of conventional legal ethicists, critiquing their theories under a typology of "moralism" and "proceduralism." The moralists misconceive litigation ethics by urging litigators to inject more of their personal moral beliefs into their professional work-thus distorting the nature of power in the law. The proceduralists, in contrast, embrace their supposedly amoral role within the legal system as a whole-thus distorting the nature of justice in the law. Section III presents a proposal for reconstructing litigation ethics based on Niebuhrian moral realism. In our adversarial legal system, the ethical litigator is a master of the maneuvers of power whose legal judgments help shape the justice of our laws and legal processes. $^{6}$ The unethical litigator is one who neither acknowledges this power nor accepts responsibility for the effects of her legal judgments.

\section{Niebuhr's Political Ethics}

Reinhold Niebuhr was a Protestant minister who wrote and spoke on pressing political issues from the church which he led in Detroit from 1915 to 1928, and from his chair of Applied Christianity at Union Theological Seminary in New York from 1928 until his death in $1971 .^{7}$ His work exercised profound influence over American political thinkers, especially from the 1930 's through the $1950{ }^{\prime} \mathrm{s}^{8}$ While clearly working from within the traditions of the Christian religion, Niebuhr has been widely appreciated by persons outside that religion, and by persons who identify

6. A fundamental point in this Note is that litigators' decisions affect the norms of law. In our legal system, judges play a passive, neutral role, leaving to the parties (the litigators) the initiative to shape the case. See, e.g., M. Damaska, The Faces of Justice and State Authority 135-140 (1986). For examples of how litigators affect the law, see infra text accompanying notes 60-67.

7. For biographical details of Niebuhr's life, see generally R. Fox, Reinhold NiebuHR: A BIOGRAPHY (1985).

8. Schlesinger, The Political Conscience of Reinhold Niebuhr, Esquire, Dec. 1983, at 394. Schlesinger summarizes Niebuhr's influence as follows:

Singlehandedly, Niebuhr accomplished a revolution in American liberal thought. His skepticism about fallible man's pretensions to infallibility, his warnings against messianism and utopianism, his ironic portrayal of the gap between righteous purpose and ruthless result, had profound influence after the [Second World W]ar on intellectual and (a few) political leaders. George Kennan called him "the father of us all." Ironists in politics like Adlai Stevenson and John F. Kennedy valued not only his philosophical slant but also his practical wisdom. As chairman of Americans for Democratic Action, he expounded the chastened and self-critical but still resolute liberalism that flowed into Kennedy's New Frontier.

Id. at 399 . 
with no religion. ${ }^{9}$ There has been a resurgence of interest in his work in the last decade. ${ }^{10}$

For present purposes, Niebuhr's most important work is Moral Man and Immoral Society, published in $1932 .{ }^{11}$ This book is an extended attack on liberalism's idealistic misconceptions about the real workings of power. ${ }^{12}$ The liberalism Niebuhr criticized could be characterized as an attitude of strong optimism and hopefulness concerning human nature and society, a belief in the manageability of social conflict through the education and moral improvement of human nature. ${ }^{13}$

To reconstruct the foundations of this liberalism, Niebuhr sets up a fundamental distinction between moralists and realists, and calls his own approach moral realism. In an important passage, Niebuhr writes:

Any justice which is only justice soon degenerates into something less than justice. It must be saved by something which is more than justice. The realistic wisdom of the statesman is reduced to foolishness if it is not under the influence of the foolishness of the moral seer. The latter's idealism results in political futility and sometimes in moral confusion, if it is not brought into commerce and communication with the realities of man's collective life. ${ }^{14}$

Niebuhr's ethics of moral vision and realistic wisdom is frankly dualistic.

9. An example is Justice Felix Frankfurter's comment to Niebuhr after hearing a sermon of his: "[A]fter the service I said to him, 'Reinie, may a believing unbeliever thank you for your sermon?' He said, 'May an unbelieving believer thank you for appreciating it?' " F. Frankfurter, Felix FRANKFURTER REMINISCES 291 (H. Phillips ed. 1960), quoted in Rice, Felix Frankfurter and Reinhold Niebuhr: 1940-1964, 1 J.L. \& Religion 325, 328 (1983) (correspondence essay).

10. Niebuhr's thought has been used-some say misused-by President Carter, see Miller, In Strange Company, New Republic, Apr. 21, 1982, at 27, 28; Schlesinger, Reinhold Niebuhr's Role in American Political Thought and Life, in Reinhold Niebuhr: His Retigrous, Social, and Political Thought, supra note 2, at 189, 220; and by George Gilder, see G. Gilder, Wealth AND PoverTY 268-69 (1981); Miller, In Strange Company, supra, at 29. Charges of misuse of Niebuhr by the "left" and the "right" have been raised by Robert McAfee Brown, see Brown, Reinhold Niebuhr: His Theology in the 1980s, 103 CHRISTIAN Century 66 (1986), and by Michael Novak, see Novak, Reinhold Niebuhr: Model for Neoconservatives, 103 Christian CENTURY 69 (1986).

11. R. Niebuhr, supra note 4. This Note will also draw in part on Niebuhr's book, The Children of Light and the Children of Darkness, R. NIEBUHR, supra note 5. These works are Niebuhr's most political and least theological books. For a systematic exposition of Niebuhr's theology, see 1 R. Niebuhr, The Nature and Destiny of Man (1941) and 2 R. Niebuhr, The Nature and Destiny of Man (1943).

12. Moral Man and Immoral Society bases much of its attack on liberalism on a distinction between the ethics of individuals and the ethics of groups. This distinction, however, is problematic, and it will not figure in the analysis here-the argument for moral realism can stand on its own. For a similar critique of this distinction, see R. Fox, supra note 7 , at 144, and R. STONE, REINHOLd Niebuhr: Prophet to Politicians 84 (1972).

13. For a discussion of the concept of liberalism which Niebuhr attacked, see Schlesinger, supra note 10, at 190-95, and Williams, Niebuhr and Liberalism, in ReINHOLD NiEbuHR: His Religious, Social and Political Thought, supra note 2, a: 269-89.

14. R. Niebuhr, supra note 4 , at 258 . Niebuhr recasts this point in The Children of Light and the Children of Darkness as the distinction between those who hold to a "too consistent pessimism" about human potential for justice and those who hold to a "too consistent optimism." R. NIEBUHR, supra note 5 , at xiii-xiv. 
He writes, "An adequate political morality must do justice to the insights of both moralists and political realists." two ways of conceiving ethical questions are hermetically sealed off from each other. The two always "interpenetrate."16 Each perspective requires the other to maintain itself, and it is only the two in combination which can form an adequate ethics. It is easy to see how moralism is concerned with ethics; the Niebuhrian insight is that because power is essential to the quest for justice, realism is also concerned with ethics. This Note will show that moralists and realists in ethics are generally incapable of appreciating the necessary insights of one another and that an adequate ethics must hold the two in creative tension.

Niebuhr's underlying conception of human society is fundamentally Augustinian or Hobbesian. ${ }^{17}$ He was sharply aware of the factors of selfinterest and power in all communal life.

What is lacking among all these moralists ... is an understanding of the brutal character of the behavior of all human collectives, and the power of self-interest and collective egoism in all inter-group relations. . . . They do not see that the limitations of the human imagination, the easy subservience of reason to prejudice and passion, and the consequent persistence of irrational egoism, particularly in group behavior, make social conflict an inevitability in human history, probably to its very end. ${ }^{18}$

This basic conflict of power with power is ignored by moralists to the peril of their goals of social improvement. Niebuhr shared in many goals of social reform; he wrote over seven hundred articles, many of which were timely appeals for social reform in industrial relations, race relations, foreign affairs, and other pressing current issues. ${ }^{19}$ Underlying these practical proposals, however, was a consistently realistic assessment of human prospects. Niebuhr would probably agree with the remark of

\footnotetext{
15. R. NIEBUHR, supra note 4 , at 233 .

16. Id. at 4 .

17. "[Niebuhr's experience in] Detroit had persuaded him that liberal Christianity, with its sentimental and optimistic view of man, was hopelessly irrelevant to the power realities of industrial capitalism. A more searching conception of human nature was required, and this Niebuhr found in the tragic insights of Augustine and Calvin." Schlesinger, supra note 8, at 396; see also R. STONE, supra note 12, at 104 (on Niebuhr's Augustinianism).

18. R. Niebuhr, supra note 4, at xx. This argument should not be limited to "collectives" but applied to individual relations as well. See supra note 12 .

19. For a bibliography of Reinhold Niebuhr's published writings, see REINHOLd NiEbuHR: His Religious, Social and Political Thought, supra note 2, at 531-68. For example, as a minister in Detroit in the 1920's, Niebuhr supported the organization of auto workers to give them more power against the oppressive labor practices of their employers. In the 1930's Niebuhr criticized John Dewey and others for their naive belief that social engineering - without accounting for the profound interest-group conflicts tearing apart American social life-could create a new society. In the 1940's Niebuhr was an early architect of the Cold War strategy of containment; he argued that American values of democracy and liberty could not be protected or advanced without realistic geopolitical power strategies. See generally R. STONE, supra note 12.
} 
President Chaim Herzog of Israel in 1985: "It is not enough to be right; we must also be strong."20

There is also an epistemological dimension to Niebuhr's presupposition of social conflict. Reason is not capable, in his view, of rising to a vantage point above conflict to resolve it objectively. On the contrary, "reason is always, to some degree, the servant of interest in a social situation."21 While Niebuhr saw reason as an instrument to criticize the fallible and partial pretenses of human action, he was wary that reason is also the vehicle by which we seek "to give the sanctity of a false universality to [our] particular needs and partial insights." 22 Thus, every rational analysis and seemingly reasonable argument is seen by Niebuhr as provisional and in need of on-going scrutiny and criticism.

This view of political ethics as moral realism is reflected in one of Niebuhr's few passages on "civil" or "positive" law. In this passage, Niebuhr sets up the tension in law which is the analytical focus of this Note:

Usually the norms of law are compromises between the rationalmoral ideals of what ought to be, and the possibilities of the situation as determined by given equilibria of vital forces. The specific legal enactments are, on the one hand, the instruments of the conscience of the community, seeking to subdue the potential anarchy of forces and interests into a tolerable harmony. They are, on the other hand, merely explicit formulations of given tensions and equilibria of life and power, as worked out by the unconscious interactions of social life. ${ }^{23}$

Reaching for the ideals of justice yet open-eyed about the present limits of power-this is the paradox of moral realism. Law serves both functions in the paradox at the same time. Legal ethicists, however, have a propensity for stressing one function to the exclusion of the other.

\section{A Critique of Conventional Legal Ethics}

Contemporary legal ethicists have not understood this fundamental tension underlying law in American society. They fail, in particular, to see that the tension cannot be resolved. Efforts to resolve the tension in either direction result in misconstruing litigation ethics. This section will develop a typology of conventional legal ethics based on Niebuhr's political ethics.

Legal ethics scholars fall broadly into two types: those who focus on the

20. Quoted in M. Kampelman, Remarks by Ambassador Max M. Kampelman at the Council of Jewish Federations (Nov. 16, 1985), reprinted in 131 CoNG. Rec. S16087 (daily ed. Nov. 21, 1985).

21. R. Niebuhr, supra note 4, at xiv-xv. For a critique of Niebuhr's view of reason in Moral Man and Immoral Society, see R. Fox, supra note 7, at 138-140.

22. 1 R. NiEBUHR, supra note 11 , at 302 .

23. 2 R. Niebuhr, supra note 11 , at 266-67. 
personal ethics of lawyers in the system and those who focus on justifications for the established system of rules demarcating appropriate lawyer conduct. This Note will call the former category of legal ethics scholarship moralism; it will call the latter category proceduralism. ${ }^{24}$ It will argue that the moralists fail to comprehend the conflicts of power underlying legal procedures and that the proceduralists fail to comprehend the importance of the legal judgments of litigators in legitimating the power of the law. This typology is an adaptation of Niebuhr's moral realism, applying his view of moralism and realism to legal ethics. ${ }^{25}$

\section{A. The Failures of Moralism}

Moralism in legal ethics is the focus on the personal ethics of participants in the legal system. Two examples of moralism are the roledifferentiated morality of Gerald Postema ${ }^{26}$ and the anarchistic ethics of William Simon. ${ }^{27}$ The first form of moralism concentrates on the personal ethics of individual lawyers in whatever legal system they practice. The second form of moralism advocates a transformation of the adversarial legal system to heighten the importance of lawyers' personal concerns for justice. After a brief look at the first form, this subsection will focus most closely on Simon's position.

\section{Role-differentiated Morality: Are Lawyers Really Different?}

One important school of legal ethics is based on the concept of the roledifferentiated morality of lawyers. ${ }^{28}$ "Role-differentiation" is a sociological term that emphasizes the alienation between the self and the expectations placed on the self by various roles. ${ }^{29}$ Postema's legal ethics draws on this concept. He writes, "In a large portion of [a lawyer's] daily experience, in which he is acting regularly in the moral arena, he is alienated from his own moral feelings and attitudes and indeed from his moral per-

24. This typological distinction is original to this Note, and is derived chiefly from Niebuhr's political philosophy. The proposed typology adapts Niebuhr's moralist/realist distinction to the particular characteristics of litigation ethics.

25 . As with every typology, these categories inevitably oversimplify the positions held by individual ethicists in each type. To mitigate this difficulty, this Note will take up representative writers in each type-one writer in each category in some detail, and others at least by outline and notes. The writers were chosen both because they make their case particularly well, and because they have been generally influential.

26. Postema, Moral Responsibility in Professional Ethics, 55 N.Y.U. L. REv. 63 (1980).

27. Simon, The Ideology of Advocacy: Procedural Justice and Professional Ethics, 1978 Wis. L. Rev. 29 [hereinafter Simon, Ideology of Advocacy]; Simon, Ethical Discretion in Lawyering, 101 Harv. L. Rev. 1083 (1988) [hereinafter Simon, Ethical Discretion].

28. Richard Wasserstrom pioneered this approach in legal ethics. See Wasserstrom, Lawyers as Professionals: Some Moral Issues, 5 HUM. RTS. 1 (1975). Postema has subsequently refined the concepts. See Postema, supra note 26.

29. The concept of role-differentiation originated with the sociologist Erving Goffman. See G. Hazard \& D. Rhode, The Legal Profession: Responsibility and Regulation 109 (1985). 
sonality as a whole."30 In other words, the legal system places expectations on the lawyer which he must fulfill as part of his role, quite apart from his own moral evaluation of what he is being asked to do. Over time his moral personality becomes alienated from his work. Postema proposes that more of the lawyer's own moral personality should be engaged in his decisions as a lawyer.

The fundamental problem with Postema's approach is that rolealienation is not unique to lawyers. Alienation is endemic to every kind of work that is not completely self-sufficient and self-expressive. ${ }^{31}$ Karl Marx, to take a well-known example, longed not only for a classless society but also for a role-less society, transcending the division of labor. ${ }^{32}$ Perhaps we all share such longings. But Postema is short-sighted to put this burden solely on lawyers. Why whine about how tough it is to be a lawyer and a person, when it is so hard to be just a person? While this approach has some social-psychological value in helping us generally understand alienation in work, it does not help us understand the issues inherent in legal ethics.

\section{Over the Abyss: Moralism and Anarchy}

William Simon carries Postema's argument a step further, bringing it into the distinctively legal arena. According to Simon, not only should individual lawyers be encouraged to bring personal ethical principles into their advocacy decision-making, but the whole system of advocacy should be recast to make this its primary goal. In this system, lawyers and their clients would debate and agree on the means as well as the ends of their cases. Simon's conclusions and recommendations illustrate the abyss of anarchism and illusion over which hangs the question of conscience in legal practice. Simon brings legal ethics to this abyss unknowingly, since he does not discuss the political premises underlying his recommendations. A close look at Simon's ideas will show the importance of political theory in the study of legal ethics, and the particular value of a Niebuhrian perspective.

30. Postema, supra note 26 , at 79.

31. Examples of such alienation include the assembly line (where control is out of one's hands and uniform processes suppress autonomy), the big business organization (as in W. WHYTE, THE ORGanization MAN (1956)), and the ordained ministry (ordained ministers "marry the church," resulting in dilemmas for those who have real spouses). See generally R. Schacht, Alienation (1970) (discussing historical and philosophical origins of concept of alienation and describing its modern forms).

32. See, e.g., K. Marx \& F. Engels, The German Ideology, in Basic Writings on Politics AND Philosophy 254 (L. Feuer ed. 1959):

[I]n communist society, where nobody has one exclusive sphere of activity but each can become accomplished in any branch he wishes, society regulates the general production and thus makes it possible for me to do one thing today and another tomorrow, to hunt in the morning, fish in the afternoon, rear cattle in the evening, criticize after dinner, just as I have a mind, without ever becoming hunter, fisherman, shepherd, or critic. 
Simon criticizes the existing conceptions of a lawyer's role, which he refers to collectively as "the ideology of advocacy." He argues that lawyers hide behind this ideology, and in their acquiescence to their supposed role in the system they perpetuate the structures of the status quo. Simon proposes a new form of legal self-understanding and practice that he calls "non-professional advocacy." He writes that "[t]he foundation principle of non-professional advocacy is that the problems of advocacy be treated as a matter of personal ethics." ${ }^{\text {"3 }}$ How do personal ethics influence legal practice? "The non-professional advocate presents himself to a prospective client as someone with special talents and knowledge, but also with personal ends to which he is strongly committed." ${ }^{34}$ How is the lawyer-client relationship then structured?

[T]he major principle of conduct is this: advocate and client must each justify himself to the other. . . . Each must justify the goals he would pursue and the way he would pursue them. In this manner, the advocate-client relation is reconstructed in each instance by the participants themselves. It is not set in advance by formal rules. . . . Advocate and client may become friends, not in Fried's sense, but in the more familiar sense of an intimacy made possible by shared ends and experience. ${ }^{35}$

The foundation of advocate-client relations, according to Simon, is mutuality based on personal sharing. The client (if that term still applies) must accept the personal goals of the attorney offering legal assistance; the attorney must also accept the client's goals, unless both attorney and client agree to be neutral with regard to each other's goals.

This approach affects the legal system as a whole, not just the lawyer's ethical self-understanding. Simon notes that "[t]he prevailing patterns of the regulation of law practice, the practices of the courts, and the style and substance of legal rules and doctrine" would all need revision. ${ }^{36}$ Simon recommends consideration of a variety of "de-professionalizing" reforms of legal practice. ${ }^{37}$ But even systemic reforms could fall short of realizing the goals of personal ethics in the legal system. He explains:

Progress toward this goal would depend on the particular ends which people brought to the judicial process, and on the extent to which the conflict unleashed by non-professional advocacy led to the enhanced sharing of concrete ends necessary to a social order in

33. Simon, Ideology of Advocacy, supra note 27, at 131 (emphasis in original).

34. Id. at 132.

35. Id. at 133 (referring to Fried, The Lawyer as Friend: The Moral Foundations of the LawyerClient Relation, 85 YALE L.J. 1060 (1976)).

36. Id. at 140 .

37. Id. at $140 \mathrm{n} .245$. While he qualifies his use of the label "non-professional advocacy" in his more recent article, his basic position, with all its implications, is unchanged. See Simon, Ethical Discretion, supra note 27 , at 1084 n.1. 
which individuality can flourish. The change would thus require a certain amount of optimism .... ${ }^{38}$

Thus even a legal system reformed along the lines Simon proposes could encourage human flourishing only if people brought to it the right goals and if the conflict inherent between persons was transmuted into an "enhanced sharing."

Here the political theory implicit in Simon's ethical system becomes apparent. His position depends on the principles of anarchy and could be called anarchistic ethical idealism. ${ }^{30} \mathrm{He}$ assumes that once all the restraints of professional rules have broken down, and lawyers and clients start relating to each other simply as people, a creative unleashing of pent-up social conflict will create a new, more fluid social order, one that is more nourishing to individual human potential. At one point he makes this assumption explicit:

The case against adversary advocacy rests in substantial part on the conviction that the pursuit of conflict is often better than its sublimation, that conflict can unleash creative energies, that it can promote understanding and personal growth, and that it can even lead to the sharing of values needed for its just resolution. ${ }^{40}$

Simon believes that intensifying social conflict can strengthen the values of individuality and genuine sharing, whereas the ideology of advocacy results in an "anesthetized acquiescence."

In one sense Simon is right, that the adversarial legal system sublimates conflicts by diverting them from homes, neighborhoods, and markets to the formal rituals of procedural justice. This often prevents people from taking the law into their own hands, anesthetizing their participation.

But that is just the point in a "government of laws, and not of men."12 Simon's anarchism, which has been shown to be the outcome of his moralism, threatens the rule of law. Niebuhr would call this optimistic, anarchical conviction "illusion," because "it will never be possible to insure moral antidotes sufficiently potent to destroy the deleterious effects of the poison of power upon character." 43 Niebuhr's entire book, The Children

\footnotetext{
38. Id. at 142 (citation omitted) (emphasis added).

39. This is this Note's term, not Simon's.

40. Simon, Ideology of Advocacy, supra note 27, at 129 (footnote omitted).

41. Id.

42. Massachusetts Declaration of Rights, pt. 1, art. 30 (1780), quoted in Marbury v. Madison, 5 U.S. (1 Cranch) 137, 163 (1803); United States v. United Mine Workers of Am., 330 U.S. 258, 307-08 (1947) (Frankfurter, J., concurring).

43. R. Niebuhr, supra note 4, at 21 . Indeed, this critique applies to lawyers themselves, who are certainly not immune from the effects of power upon character. From the perspective of society, justice often cannot be achieved without individuals asserting their self-interest; yet Simon would seem to put the oppressed who seek justice at the mercy of moralizing lawyers. Here proceduralism provides an important antidote, in focusing on the autonomy of individuals in their use of legal processes for their
} 
of Light and the Children of Darkness, written in the waning days of World War II, is a discourse on this "error of a too great reliance upon the human capacity for transcendence over self-interest" 4 in situations of conflict. He would call Simon's error that of "a too consistent optimism in regard to man's ability and inclination to grant justice to his fellows," an error which "obscures the perils of chaos which perennially confront every society, including a free society." the optimistic expectation of human growth is the potential "war of all against all" in the Hobbesian state of nature, a war which invites the alternative evil of tyranny.

This is the abyss over which moralism in legal ethics hangs. It reminds us that legal ethics is but a species of political philosophy. Simon's political premises thoroughly control his legal ethics. The consequences of Simon's moralistic re-visioning of legal practice raise hard questions for legal ethics: If an ideal of personal ethics in legal practice leads this far, must lawyers mute their ethical concerns in order to practice their profession? Can lawyers bring personal ethical concerns to their legal practice, or is "legal ethics" an oxymoron, a contradiction in terms? This is the position taken by the other major type of legal ethicists, the proceduralists.

\section{B. The Failures of Proceduralism}

Proceduralism in legal ethics focuses on the established system of rules that shape lawyers' actions. In this view, lawyers do not make ethical decisions; they are obligated merely to follow the rules. Only the system as a whole can be the subject of ethical reflection; lawyers' day-to-day work is amoral. While the forms of proceduralism vary according to the kind of justifications that are proposed for the established systems of rules, ${ }^{16}$ this subsection will focus on the particular form of proceduralism based on the instrumental ethics of Stephen Pepper. ${ }^{47}$ It will show why proceduralism is an inadequate basis for litigation ethics.

own ends. See discussion of Pepper, infra note 50 and accompanying text.

44. R. NieBuHR, supra note 5 , at 39.

45. Id. at xiii. Recall in this regard Niebuhr's line: "the foolishness of the moral seer . . results in political futility and sometimes in moral confusion, if it is not brought into commerce and communication with the realities of man's collective life." R. NiEBUHR, supra note 4, at 258; see supra note 14 and accompanying text.

46. Such justifications include: (a) the protection of individual rights embodied in legal procedures, see M. Freedman, Lawyers' Ethics in an Adversary System (1975); but see Griffiths, Ideology in Criminal Procedure or a Third "Model" of the Criminal Process, 79 Yale L.J. 359 (1970); (b) the role of the lawyer in representing a client as a special purpose friend, see Fried, supra note 35; but see Post, On the Popular Image of the Lawyer: Reflections in a Dark Glass, 75 Caurf. L. Rev. 379 (1987); and (c) the value of the adversary system in the pursuit of truth, see Professional Responsibility: Report of the Joint Conference, 44 A.B.A. J. 1159, 1160-61 (1958); but see Frankel, The Search for Truth: An Umpireal View, 123 U. PA. L. REv. 1031 (1975) (arguing that adversary system rates truth too low among values that institutions of justice are meant to serve); Gerber, Victory vs. Truth: The Adversary System and its Ethics, 19 ARIz. ST. L.J. 3, 5 (1986-87) (describing courthouse as "lawyers' playpen"). See generally M. DAMASKA, supra note 6.

47. For a good illustration of Pepper's views, see Pepper, The Lawyer's Amoral Ethical Role: A 
Pepper's proceduralist legal ethics sees lawyers as tools or amoral technicians that enable citizens to exercise their legal rights. According to this view, lawyers are mere extensions of their clients' interests. A lawyer makes it possible for a client to achieve her goals within the bounds and through the means of the law. Pepper notes the apparent moral contradiction between what lawyers do qua lawyers for their clients and the universal ethical obligations of lawyers as human beings. This is the same dilemma addressed by Postema, ${ }^{48}$ but Pepper comes out on the other side. He defends the role-differentiated morality of legal practice. He says that "conduct by the lawyer in service to the client is judged by a different moral standard than the same conduct by a layperson. . . . As long as what lawyer and client do is lawful, it is the client who is morally accountable, not the lawyer." 40 The only standard of evaluation is whether the lawyer has effectively helped the client reach her goals within the bounds of law. The lawyer's work is thus, to the lawyer, amoral.

Pepper's argument runs as follows:

Our first premise is that law is intended to be a public good which increases autonomy. The second premise is that increasing individual autonomy is morally good. The third step is that in a highly legalized society such as ours, autonomy is often dependent upon access to the law. Put simply, first-class citizenship is dependent on access to the law. . . . For most people most of the time, meaningful access to the law requires the assistance of a lawyer. Thus the resulting conclusion: First-class citizenship is frequently dependent upon the assistance of a lawyer. If the conduct which the lawyer facilitates is above the floor of the intolerable-is not unlawful-then this line of thought suggests that what the lawyer does is a social good. The lawyer is the means to first-class citizenship, to meaningful autonomy, for the client. ${ }^{80}$

Pepper focuses on the lawyer as agent of the client's ends. Lawyers do not bring their own ends to the relationship, nor should they function as a kind of "moral screen" to their client's ends. Rather, there must be "equality of access" in the sense that clients should not have to filter their goals unequally through the disparate moral views of each individual lawyer. ${ }^{51}$ The lawyer's conscience is subordinated to that of the client.

The image for a lawyer's task that Pepper adopts is that of a technician. He presents a picture of

the individual facing and needing to use a very large and very com-

Defense, A Problem, and Some Possibilities, 1986 AM. B. Found. Res. J. 613.

48. See Postema, supra note 26.

49. Pepper, supra note 47 , at 614 .

50. Id. at 617 (footnote omitted).

51. Id at 617-18. 
plicated machine (with lots of whirring gears and spinning data tapes) that he can't get to work. This is "the law" that confronts the individual in our society ... . [who therefore] needs a technician (or mechanic) to make it go. ${ }^{52}$

The lawyer is like an auto mechanic who is morally unconcerned with the purpose for which the client will use the fixed car.

Pepper's first problem is that he has not thought through the morality of auto mechanics. The difference between a lawyer and an auto mechanic lies in the kind of information each has about her client's ends. A lawyer tends to know more about the ends of her work, which makes her work more troubling. If an auto mechanic knew she was fixing a car so it could be used to commit a bank robbery, her "amorality" would quickly disappear. Auto mechanics typically do not face the dilemma of a contradiction between public and private knowledge; this contradiction, on the other hand, is intrinsic to lawyering.

Pepper's second problem is his conception of the kind of legal service which lawyers provide for their clients. He has tried to avoid any adversarial justification for what lawyers do. In the process he has avoided what it is that lawyers in fact do. By adopting a mechanical model which seems appropriate for document drafting or other office tasks, as opposed to litigation, he ignores the relationship between such tasks and potential litigation. Consider drafting a will, for example. At first glance it may look like a mechanical application of the arcane rules of devising property. Will-drafting may be done in an office, but that office is in the shadow of the courthouse. The arcane rules are employed with care because the will could well be contested. Lurking behind every phrase are potential conflicts over property, contests over power. This is not to reduce all of legal practice to litigation, but it is to suggest that "use" of the law rarely involves only the client. In every invocation of legal process there is always potential, if not actual, social conflict over power at stake.

The third and most important problem for Pepper is his conception of the law. The metaphor of a whirring machine suggests that law is an impersonal structure of carefully engineered parts. This further implies that the law is itself rigid and unchanging, since machines are not ordinarily affected by the uses to which they are put (as long as they are used properly). A Niebuhrian perspective on law as the juncture of power and justice provides a much richer and more accurate picture of the law than Pepper's machine. Seen as conflict over power, legal process directly changes the way private parties battle. They must battle within the terms law provides. Machines do not change their operators, but law transforms society. ${ }^{53}$ Seen as a quest for justice, the law is not a static machine that

52. Id. at 623-24.

53. This point is consistent with proceduralists who do not take as static and mechanical a view of 
need only be properly oiled and maintained; law is more like a living organism that grows and changes teleologically both from internal imperatives and from interacting with its environment. ${ }^{54}$ Litigators' decisions affect the form and substance of the law. ${ }^{\mathrm{st}}$

Proceduralists may acknowledge the importance of morality in the legal system, as Pepper does, a morality which inheres in the rules of the system itself. The moral lawyer need then only follow the rules, or properly use the machine, to stay with Pepper's metaphor. However, this view misperceives the source of legal norms: Lawyers are not only norm-takers, they are also norm-givers, since their chosen actions actually change the law (hence producing new legal norms). Proceduralists thus abdicate moral responsibility; their ethics translates into a political philosophy of unregulated self-assertion, which, as Niebuhr points out, leads only to ceaseless struggle. Niebuhr writes:

A too consistent political realism would seem to consign society to perpetual warfare. . . . If self-interest cannot be checked without the assertion of conflicting self-interests how are the counter-claims to be prevented from becoming inordinate? And if power is needed to destroy power, how is this new power to be made ethical? ${ }^{\text {se }}$

The proceduralist has no way to connect ethical concerns with the way litigators actually use the power of the law. This is the proceduralist counterpart to the anarchism of unleashed personal moralism; for while the moralist's illusions about power and human nature consign society to a war of competing personal beliefs with no restraining rule of law, the proceduralist's confidence in the systemic rule of law divorces responsibility for that system from the daily decisions of litigators. The moralists believe they can transcend the perils of power in their quest for justice; the proceduralists believe they can dispense with the quest for justice in their use of power. ${ }^{6 z}$

Thus Pepper's model fails to comprehend the character of power and

the law as Pepper. See, e.g., Hazard, Quis Custodiet Ipsos Costodes? (Book Review), 95 YALE L.J 1523 (1986) (reviewing K. Mann, Defending White Collar Crime (1985)).

54. Recall the quote from Niebuhr on the organic character of law in relation to society, supra note 23 and accompanying text.

55. The ways in which lawyers play a "mediating" function between law and private actors is developed in Section III, infra.

56. R. Niebuhr, supra note 4, at 231. Recall in this connection the earlier lines from Nisbuhr: "Any justice which is only justice soon degenerates into something less than justice. It must be saved by something which is more than justice." Id. at 258; see supra note 14 and accompanying text.

57. The twin horns of this dilemma are captured by Niebuhr when he writes, on the one hand, that the "unhappy consequence of a too consistent political realism would seem to justify the interposition of the counsels of the moralist. He seeks peace by the extension of reason and conscience;" and yet on the other hand, "the moralist may be as dangerous a guide as the political realist. He usually fails to recognise the element of injustice and coercion which are present in any contemporary social peace." Niebuhr's conclusion, therefore, is that "[a]n adequate political morality must do justice to the insights of both moralists and political realists." R. NIEBUHR, supra note 4, at 232-33. 
justice inherent in legal practice. The technician provides no more help in maneuvering through the "brutalities of power" than Simon's zealot. A lawyer is not a mere conduit between solitary clients and the whirring engine of the law. ${ }^{\mathbf{5 8}}$ Pepper's amoral mechanical metaphor fails to capture the human drama of litigation, with all its complex characters, conflicts, plots, and settings. Litigators direct this drama in the public fora of the law. Better metaphors for lawyers' work might be found in politics. But even the mastery of the manipulations of power would not be sufficient to make an ethical litigator. Litigators' judgments affect the law itself; they cannot abjure responsibility for these changes. Proceduralism's amorality fails to account for the distinctive character of the knowledge which litigators handle, the social conflicts within which litigators use this knowledge, and the public demands for justice placed upon their legal judgments. Litigators' work is inherently moral in the public shape which it gives to human conflicts over power.

\section{Legitimating Power: Towards a Niebuhrian Litigation ETHICS}

We have seen that a Niebuhrian political ethics brings to light the weaknesses of the assumptions of leading legal ethicists. Neither the moralists nor the proceduralists can adequately illuminate the fundamental tensions in American legal practice. Every resolution toward one side or the other can be shown to be partial and misleading. Nevertheless, in the face of this theoretical deficiency such provisional resolutions must be made in legal practice every day. Can Niebuhr's political philosophy supply not only critical theory, but also a basis for a constructive theory of litigation ethics?

The problems may be insoluble in principle, but there are proximate solutions and criteria for evaluating these solutions. While Niebuhr never addressed the issues of legal ethics, certain themes implicit in the Niebuhrian critique of moralism and proceduralism developed in the previous Section can be brought to the surface and expounded. In this light, this Note contends that the key question for litigation ethics should be this: How does a litigator mediate between the state's interest in the litigation and the private parties' struggle for power through the law? This question puts political theory front and center in legal ethics. It sees the ethical dimension of litigation in the extent to which litigation requires private parties to conform to public norms in their battle for power and in the extent to which decisions of litigators affect the norms of the law. It looks to the decisions of individual litigators not to infuse their personal visions of justice into their clients' cases but to mediate the private goals and re-

58. Nor is a lawyer a mere conduit to the various goals offered by other forms of proceduralism, whether these goals are conceived as truth, individual rights, or friendship. See supra note 46 . 
sources of their clients and the public drama of justice in the adversarial legal system. This question can guide both litigators and those who oversee litigation..$^{59}$

The term "mediate" needs explanation. The sociologist Talcott Parsons developed the concept of the lawyer as mediating public norms to private conduct. ${ }^{60}$ Parsons argued that private actors must conform (or at least respond) to public norms of justice when they seek to use the legal system in their struggles for power; it is lawyers who inform private actors concerning these norms and who form or transform the interests of private actors to fit the public norms in the course of legal conflicts. As Robert Gordon has put it, in his explanation of this Parsonian perspective:

The lawyer's job . . . is to mediate between the universal vision of legal order and the concrete desires of his clients, to show how what the client wants can be accommodated to the utopian scheme. The lawyer, thus, has to find ways of squeezing the client's plan of action into the legally recognized categories of approved conduct. ${ }^{\text {BI }}$

In this sense lawyers do mediate public norms to private interests. Parsons was only half correct, however. The Niebuhrian approach in

59. Those who oversee litigation fit Niebuhr's hopes for the "children of light":

The children of light must be armed with the wisdom of the children of darkness but remain free from their malice. They must know the power of self-interest in human society without giving it moral justification. They must have this wisdom in order that they may beguile, deflect, harness and restrain self-interest, individual and collective, for the sake of the community.

R. NiEBuHR, supra note 5, at 41.

60. See Parsons, A Sociologist Looks at the Legal Profession, in Essays on Soctological THEORy 370 (T. Parsons ed. 1954); Parsons, The Law and Social Control, in LAw AND Sociology 56 (W. Evan ed. 1962). Parsons' view of lawyers was part of his larger functionalist sociological theory. In a complex, differentiated society, Parsons contended, there have to be some shared values or overarching norms that orient diverse interest groups to some common purposes. In an earlier age, this may have been the role of theology. In modern societies, law is an important source of general norms. Part of the role of lawyers, then, is to mediate these norms to their erstwhile private clients, helping align their clients' interests with general social norms. See also Gordon, The Independence of Lawyers, 68 B.U.L. REv. 1, 17-18 (1988) (discussing Parson's concepts).

This view of the social role of lawyers predates Parsons. however, and need not be tied to his sociological theory. See, e.g., The Federalist No. 35, at 216 (A. Hamilton) (C. Rossiter ed. 1961) (lawyer as "an impartial arbiter" between "the rivalships" of society, promoting various interests with an eye "to the general interests of the society"); A. TOCQUEville, DEMOCRACY IN AMERICA 243 (J. Mayer \& M. Lerner eds., G. Lawrence trans. 1966) (viewing lawyers in America as a separate estate, an "aristocracy" that provided a social balance between impulses of radical democracy and selfinterested industry); L. BrandeIs, The Opportunity in the Law, in Business-A Profession 329 337 (1933) (address delivered May 4, 1905, before Harvard Ethical Society) (lawyers should hold "a position of independence, between the wealthy and the people, prepared to curb the excesses of either ...."). The concept of lawyer as mediator need not be tied to broader theories of functionalist sociology, civic republicanism, or liberal legalism.

Recently, Robert L. Nelson has used this concept in his study of lawyers in four Chicago law firms. See R. Nelson, Partners With Power 232, 266 (1988). Another variation on this model of mediation has been developed in a book review by Geoffrey Hazard. See Hazard, supra note 53.

61. Gordon, The Ideal and the Actual in the Law: Fantasies and Practices of New York City Lawyers, 1870-1910, in The New High Priests: Lawyers in Post-Civil War America 51, 53 (G. Gawalt ed. 1984) (emphasis added). 
this Note differs from Parsons' in that it contends not only that lawyers mediate public norms to private actors through the legal system, but that litigators' decisions on the conduct of their cases also affect the legal system. Litigators are not only law-takers, they are also law-makers. ${ }^{62}$ The ways litigators frame legal struggles-and their decisions regarding the use of available legal strategies-change the substance and form of public norms. Examples of such changes include: (1) the use of discovery as a financial burden on one's opponent, reducing the likelihood of a case being brought in the first place, and changing the likelihood and terms of settlement; ${ }^{68}$ (2) the choice of which cases to settle and which to bring to trial, especially by corporate and civil rights "repeat players" trying to change the substantive law; ${ }^{64}$ and (3) deciding generally which points of law to ask courts to adjudicate, and deciding specifically which cases and which points to appeal, knowing appellate courts (especially supreme courts) will take a special look at the precedential effects of the issues involved. ${ }^{\text {Bs }}$ In a civil law or inquisitorial legal system, these examples

62. This weakness in Parsons' approach is important because Parsons' view of mediation can be accommodated to proceduralism-lawyers as technicians helping their clients understand how to use the machine of the law-whereas the double-edged view of mediation as changing the law as well as clients comports with the Niebuhrian dualism of moralism and realism.

63. The uses and abuses of discovery are widely debated. Some commentators emphasize the threats posed by litigators' discovery conduct to the goals of the legal system (justice, truth, fairness, etc.), while others focus on the problems that would result from increased judicial control of discovery. Both sides acknowledge the importance of litigators' legal judgments in discovery for our adversarial legal system. See, e.g., M. Frankel, Partisan Justice 18 (1980) ("Where the object always is to beat every plowshare into a sword, the discovery procedure is employed variously as weaponry. A powerful litigant in a complex case may impose costly, even crushing, burdens by demands for files, pretrial testimony of witnesses, and other forms of discovery."); Brazil, The Adversary Character of Civil Discovery: A Critique and Proposals for Change, 31 VAND. L. REv. 1295 (1978) (strategic use of discovery by lawyers in big cases distorts the purposes of discovery); $c f$. Nelken, Sanctions Under Amended Federal Rule 11-Some "Chilling" Problems in the Struggle Between Compensation and Punishment, 74 Geo. L.J. 1313 (1986) (new controls over discovery chill innovation by creative lawyers and change balance of power in litigation); comment by Judge Jack Weinstein (May 2, 1978), quoted in D. Louisell \& G. Hazard, Cases and Materials on Pleading and ProceDURE 847 (4th ed. 1979) ("Much of the present rush to limit discovery is, in my opinion, based on a desire to close the federal court to prospective plaintiffs and make litigation more difficult for those who seek remedies."). Professor Hazard puts the controversies concerning discovery into a broader perspective. He argues that in evaluating the "litigation explosion" " and the use of obstructive litigation tactics, one should consider

not only the types of conduct directly involved but also changes in substantive law that emerge from litigation, the impact of changes in the law on behavior patterns in the community at large, relationship between the legal norms and behavior patterns, and the effects on the community's system of authority considered as a whole.

G. Hazard, Authority in the Dock, Address to the Yale Law School Program in Civil Liability (Working Paper \#77), at 1 (Conference on "Issues in Civil Procedure: Advancing the Dialogue," Yale Law School, Apr. 8-9, 1988).

64. See, e.g., Fiss, Against Settlement, 93 YaLE L.J. 1073 (1984) (making analogy between settlement and plea bargaining where consent is often coerced, bargains are struck by people without authority, and justice may not be done); Galanter, Why the "Haves" Come Out Ahead: Speculations on the Limits of Legal Change, 9 Law \& Soc'y REv. 95 (1974) (analysis of strategies used by parties who frequently litigate similar issues or with an eye to goals beyond individual case).

65. While legislators are free to introduce bills concerning any issues they please, courts (at least Federal courts) are limited by the Constitution to resolving actual "cases" and "controversies." U.S. ConsT. art. III, $\$ 2$. Thus courts are limited to the questions of law which are presented by the cases 
would have significantly less force. ${ }^{68}$ However, in our adversarial, partydriven system, the litigators' legal judgments profoundly affect the form and substance of the law. The three examples illustrate the kind of legal judgments which litigators make that do not come before judges. To the extent that litigators try to hand responsibility for all these law-changing decisions over to judges-claiming simply to represent clients and to bear no responsibility for the outcome-they ignore their centrality in our adversarial system. They have also abnegated any sense of professionalism governing their work. They have lost awareness of the peculiar power of litigators in the American legal system and of the responsibility that comes with that power. Official legal procedures are insufficient in this system to constrain litigators' actions-hence the urgency of professionalism. The Niebuhrian vision of litigator as mediator advocated in this Note can be understood as a call for a renewed sense of professional commitment among litigators. ${ }^{67}$

This way of conceiving litigation ethics in our adversarial legal system fits the Niebuhrian philosophy of moral realism. First, it is realistic. It presupposes the "brutalities of power" in the underlying social conflicts which lead to litigation in the first place. Niebuhr wrote, "Conflict is inevitable, and in this conflict power must be challenged by power." ${ }^{\text {"8s }}$ Litigation ethics must start with this perspective-not only about the social conflicts underlying litigation, but also about the role of the litigator who bears the sword in these battles. Niebuhr's description of the man of power fits the role of the experienced litigator in an important case: "The man of power, though humane impulse may awaken in him, always remains something of the beast of prey .... [tending toward] warlike sportsmanship toward those who equal his power and challenge it ... "189 Litigation ethics cannot be divorced from this reality of social conflicts over power. Nor, Niebuhr teaches, can litigation ethics dissolve into personal morality in the hope of more effectively resolving social tensions outside of a legal system. Such anarchism fails in view of the brutally selfdestructive nature of human beings.

This way of conceiving litigation ethics is also Niebuhrian in that it not

\footnotetext{
brought before them by litigators.

66. See M. DAMASKA, supra note 6. In a civil law systern: (1) the court, rather than the lawyer, prepares a dossier of the evidence; (2) the court takes a much more active role in "settlement" of disputes, leaving less room for "repeat players" strategies; (3) the court is integrated into an administrative apparatus which actively regulates the conduct of citizens by legal rules and tends to abstract the appellate process from particular facts by deciding pure logical rules of law. Id. at 22-23.

67. See L. BRANDEIS, supra note 60, at 337; see also Gordon, supra note 60 (surveying concepts of lawyer independence and assessing its desirability). Such a notion is, of course, in sharp contrast to the "non-professional advocacy" advocated by Simon, see supra notes 33-41 and accompanying text, and the amoral lawyer-as-technician advocated by Pepper, see supra notes 47-52 and accompanying text. Both moralism and proceduralism undermine the distinctive American tradition of legal professionalism epitomized by Brandeis.
}

68. R. NiebuhR, supra note 4 , at $\mathrm{xv.}$

69. Id. at 13 . 
only analyzes power, but seeks justice. Litigation ethics sees the legal process as more than merely an arena for private battles for power. It presupposes an interest in the litigation which transcends the private interests of the parties, namely the interest of the state. This keeps litigation ethics realistic, yet not cynical. For the central role of the state-underlying every action a litigator takes-forces the private battle to take a distinctively public shape. It forces the participants to frame the battle in terms of the public norms of evidence and procedure and to accept the results of the battle as determined by state-sponsored adjudication on the basis of these norms. Thus, in Niebuhr's language, litigation brings the parties under the authority of the norms of law as "the rational-moral ideals of what ought to be"; norms which are "the instruments of the conscience of the community, seeking to subdue the potential anarchy of forces and interests into a tolerable harmony."'70 The state-enforced harmony will rarely be ideal, but it will be tolerable to the extent it actually reflects the quest for justice. ${ }^{71}$

Yet it is not enough for litigators simply to hand over responsibility for justice through law to the state. Such a proceduralist move relinquishes the power litigators actually have in our adversarial legal system; $;^{72}$ it hands over responsibility for justice to institutions which can never fully embody it; ${ }^{73}$ and it fundamentally misconceives the character of legal change. ${ }^{74}$ Litigators have a professional responsibility for the justice of the American legal system. Theories of litigation ethics which abjure this claim are neither moral nor realist.

\section{Conclusion}

No litigation ethics will be adequate until it develops both a coherent political philosophy and subsequent norms for lawyers' conduct in litigation. This Note has argued that Niebuhr's political philosophy provides important insights for litigation ethics. This idea has been developed by showing how moralism and proceduralism fail to provide an adequate un-

70. 2 R. Niebuhr, supra note 11, at 266-67; see supra note 23 and accompanying text.

71. In this respect the moralists still play an important role. Moral realism is always in danger of lapsing inta cynicism; thus even the illusions of the moralists have a place in keeping the question of conscience alive in litigation ethics when they heighten concern over the legitimacy of public norms. On the necessity of some illusions, especially the "foolishness" of moralists, see R. NIEBUHR, supra note 4, at 277 (closing paragraph of book); supra note 14 and accompanying text; infra text accompanying note 75 .

72. Recall the discussion of the litigator's powers, supra notes 60-67 and accompanying text.

73. On this point even Niebuhr was not sufficiently realistic. He tended to emphasize the capacity of legal institutions to impartially adjudicate social conflicts. See R. NiEBUhr, supra note 4, at 238. However, he did recognize limits on the impartiality of law. See id. at 239. Moral realism does not exempt the state from critical scrutiny for injustices in the exercise of power. ' 'Power,' said Henry Adams, 'is poison'; and it is a poison which blinds the eyes of moral insight and lames the will of moral purpose." Id. at 6 .

74. See supra notes 52-58 and accompanying text (critique of Pepper's mechanical metaphor for law); supra note 65 and accompanying text (precedent and legal change). 
derlying political philosophy and in sketching a theory of litigation ethics built on Niebuhr's moral realism. This is only to define the nature of the task, however. The complete task of developing norms for lawyer conduct on the basis of this theory still lies ahead.

Reinhold Niebuhr's distinctive contribution to political philosophy was to place the interest in justice and social reform on the firm foundation of a realistic conception of the role of power in society. This Note has utilized his concept of power to critique the conventional study of legal ethics, proposing the centrality of political theory for any adequate litigation ethics and proposing an alternative theoretical model for litigation ethics along Niebuhrian lines. Such a model is necessary for any effort to increase the justice, equity, or freedom available through legal procedures in American society.

A final word must be said for what Niebuhr calls the "foolishness of the moral seer." of such foolishness. The danger is that realism will ossify into cynicism, and moral vision will be lost. Realism must be held in tension with moral reason and imagination. Thus, at the least, the study of legal ethics could benefit from more attention to the goals of law envisioned in philosophy, religion and literature. ${ }^{76}$ Here the etymological connection between Niebuhr's moral realism and the jurisprudential school of legal realism is also worth noting. Law is not an isolated sphere of formal conceptions sealed off from social reality, but is integrally related to the social powers, interests, and ideals which both form and are formed by legal norms. In mediating this relationship, litigators make moral decisions every day. One can hope, considering the power of the law itself in our society, that litigators who read Niebuhr will have their moral vision-as well as their thirst for combat-renewed.

75. R. Niebuhr, supra note 4, at 258; $c$. supra note 14 and accompanying text.

76. Examples that come readily to mind include M. KUNDERA, THE UNBEARABLE LightNeSS of Being (1984); M Kundera, The Book of Laughter and Forgetting (1981); D. Tracy, Blessed Rage for Order (1975); A. Whitehead, Religion and Modern Society (1926); T. WOLfE, The BonfiRe of THE VANITIES (1987). 